\title{
AS ETNOGÊNESES: VELHOS ATORES E NOVOS PAPÉIS NO CENÁRIO CULTURAL E POLÍTICO
}

\author{
Miguel Alberto Bartolomé
}

\author{
Sólo existe la lucha por recobrar lo que se ha perdido \\ Y encontrado y vuelto a perder muchas veces \\ $\mathrm{Y}$ ahora en condiciones que no parecen propicias \\ Pero tal vez no haya ganancia ni pérdida \\ Para nosotros sólo existe el intento \\ Lo demás no es cosa nuestra \\ (T. S. Eliot, Cuatro cuartetos)
}

\section{Processos de etnogênese}

O termo etnogênese tem sido usado para designar diferentes processos sociais protagonizados pelos grupos étnicos. De modo geral, a antropologia recorreu ao conceito para descrever o desenvolvimento, ao longo da história, das coletividades humanas que nomeamos grupos étnicos, na medida em que se percebem e são percebidas como formações distintas de outros agrupamentos por possuírem um patrimônio lingüístico, social ou cultural que consideram ou é considerado exclusivo, ou seja, o conceito foi cunhado para dar conta do processo histórico de configuração de coletividades étnicas como resultado de migrações, invasões, conquistas, fissões ou fusões. Entretanto, mais recentemente, passou a ser usado também na análise dos recorrentes processos de emergência social e política dos grupos tradicionalmente submetidos a relações de dominação (Hill 1996:1).

Com alguma freqüência, tem-se chamado de etnogênese o desenvolvimento de novas configurações sociais, de base étnica, que incluem diversos grupos participantes de uma mesma tradição cultural (por exemplo, os Mapuche atuais, Boccara 2000). Também já se qualificou de etnogênese o ressurgimento 
AS ETNOGÊNESES: VELHOS ATORES E NOVOS PAPÉIS NO CENÁRIO CULTURAL E POLÍTICO

de grupos étnicos considerados extintos, totalmente "miscigenados" ou "definitivamente aculturados" e que, de repente, reaparecem no cenário social, demandando seu reconhecimento e lutando pela obtenção de direitos ou recursos (Rossens 1989; Pérez 2001; Bartolomé 2004). Em outras oportunidades, recorreuse ao mesmo conceito para designar o surgimento de novas comunidades que, integradas por migrantes ou seus descendentes, reivindicam um patrimônio cultural específico para se diferenciarem de outras sociedades ou culturas que consideram diversas de sua autodefinição social, cultural ou racial (por exemplo, grupos migratórios interestatais ou comunidades afro-americanas). Sublinharei aqui que os distintos usos remetem a um mesmo tipo de dinâmica social, cuja base se encontra na historicidade de estruturas e formas culturais que tendiam a se conceberem como relativamente estáticas ${ }^{1}$. A etnogênese, ou melhor, as etnogêneses referem-se ao dinamismo inerente aos agrupamentos étnicos, cujas lógicas sociais revelam uma plasticidade e uma capacidade adaptativa que nem sempre foram reconhecidas pela análise antropológica.

Na verdade, a etnogênese foi e é um processo histórico constante que reflete a dinâmica cultural e política das sociedades anteriores ou exteriores ao desenvolvimento dos Estados nacionais da atualidade. É o processo básico de configuração e estruturação da diversidade cultural humana. Suas raízes fundem-se nos milênios e projetam-se até o presente. Há centenas de milhares de anos, quando alguns dos membros de uma tradição caçadora, falantes de uma língua comum, migravam buscando novos horizontes, separavam-se tanto cultural quanto lingüisticamente do grupo inicial a que pertenciam, dando lugar ao desenvolvimento de um novo tipo de coletividade social, lingüística e cultural. Em muitas ocasiões, os novos âmbitos ecológicos a que chegavam condicionavam suas respostas culturais ao meio ambiente, levando a maiores especializações e, conseqüentemente, a diferenciações.

Depois do surgimento e da expansão dos cultivos, algumas das aldeias agrícolas indiferenciadas das antigas sociedades igualitárias neolíticas puderam mover-se em busca de terras melhores e, com o correr dos séculos, desenvolver suas próprias criações e conquistas culturais, esquecendo, inclusive, que um dia tiveram relação entre si. Também as sociedades aldeãs integrantes das sociedades hierárquicas estatais podiam mudar de filiação lingüística e cultural ao mudarem de adscrição política como resultado de alianças ou conquistas. Esses processos pressupunham com freqüência desde a adoção, o intercâmbio, a simbiose de traços culturais até a produção de novas configurações sociais e culturais cujas características podiam distanciar-se muito das que lhes deram origem.

Trata-se, pois, da construção cultural das distintas experiências sociais e dos diversos sistemas simbólicos que as animam - o que se vincula 
tanto com a antropologia da evolução quanto com a ecologia cultural ou as antropologias econômicas e políticas². Nesse sentido, todas as culturas humanas resultam de processos de hibridação, já que a própria noção de cultura deve ser considerada um sistema dinâmico, cuja existência se deve tanto à criação interna quanto à relação externa. Em síntese, a etnogênese é parte constitutiva do próprio processo histórico da humanidade e não só um dado do presente, como parecia depreender-se das reações de surpresa de alguns pesquisadores sociais em face de sua evidência contemporânea. E a América Latina, do mesmo modo que o resto do mundo, foi e é um espaço marcado por múltiplos processos de etnogênese que se manifestam até a atualidade, embora agora inseridos no contexto da chamada globalização e de um sistema mundial. Uma breve abordagem do passado latino-americano nos possibilitará uma melhor compreensão dos processos atuais.

\section{Etnogêneses latino-americanas}

Tanto na Aridoamérica quanto na Mesoamérica, na zona intermediária, nos Andes, nas terras baixas sul-americanas e nas planícies do Chaco e da Patagônia, as tradições locais deram lugar a uma multidão de agrupamentos étnicos, cujo aspecto contemporâneo à invasão européia representava um momento do processo, mas não o momento definitivo ou definidor - apenas a configuração circunstancial de um dinamismo aberto à história. Assim, por exemplo, os Inca não eram senão o resultado, naquele momento, da milenar tradição civilizadora andina (Lorandi e Del Rio 1992), da mesma maneira que os Asteca representavam uma solidificação política, regional e temporalmente circunscrita à antiga tradição mesoamericana (López Austin e López Lujan 1996). Muitos dos grupos que originalmente conheceram os europeus eram sociedades relativamente recentes, derivados de processos migratórios, conquistas, deslocamentos, fusões de coletividades menores, fissões de agrupamentos maiores, incorporações ou fragmentações políticas etc. Esse é o caso dos Chiriguano das atuais Bolívia e Argentina, que são o testemunho do disparatado esforço expansivo de parte dos Guarani do Paraguai até o Império Inca; seus vizinhos e subordinados Chané eram (e são) um grupo arawak guaranicizado; por sua vez, os chamados "Pampa" da Argentina constituíam provavelmente o resultado da relação entre Mapuche e Tehuelche; os Wayú ou Guajiro da Colômbia e da Venezuela foram o produto de uma fusão de grupos diversos; as parcialidades guaranis do Paraguai (Cario, Tobatine etc.) respondiam a configurações locais produzidas pela dinâmica migratória e assim por diante. 
AS ETNOGÊNESES: VELHOS ATORES E NOVOS PAPÉIS NO CENÁRIO CULTURAL E POLÍTICO

Durante a época colonial alguns grupos desapareceram como resultado das compulsões militares, bióticas ou econômicas, mas também surgiram outros tantos devido a deslocamentos, congregações ou alianças. Um exemplo disto são os atuais Mískito da costa do caribe nicaragüense, que constituem a conjunção de distintas populações nativas com escravos negros, politicamente unificada em um reino apoiado pela Inglaterra desde o século XVII (Gould 1998). Caso semelhante é o dos Garífuna ou "caribes negros", que habitam as costas de Belize e Guatemala e resultam da mistura entre diferentes grupos arawak e populações de origem africana, constituídos como etnia por volta do século XVIII (Ghidinelli 1983). Por sua vez, várias sociedades nativas do Nordeste brasileiro são produto dos aldeamentos jesuíticos nos quais diferentes grupos se fundiram (Carvalho 1984). Inversamente, as parcialidades guaranis do Paraguai se devem à separação entre os que aceitaram e os que recusaram a tutela jesuíta (Bartolomé 1977, 2004).

A política colonial das "recongregações" na Nova Espanha ou da "desnaturalização" no Rio da Prata reestruturou ou deslocou uma variedade de comunidades mesoamericanas e andinas (Bartolomé 1985). Durante o mesmo período, a importação de escravos negros, e seu posterior agrupamento em comunidades mais ou menos independentes, aumentou e diversificou o panorama étnico regional. Este seria o caso das coletividades de ascendência africana procedentes de diferentes tradições culturais, mas reconstituídas em termos étnicos exclusivos e nas quais o fenótipo opera como um dos referentes identitários básicos, como os "cimarrones" da Venezuela (Guss 1996), os "kilombos" do Brasil (O'Dwyer 2002) ou os "palenques" colombianos (Fridmann e Arocha 1986). Deve-se sublinhar que não apenas uma, mas várias etnogêneses negras foram produzidas - cada uma das quais supondo a recomposição ou a reestruturação dos distintos referentes ideológicos, lingüísticos e culturais africanos, dos quais eram portadores os membros dessas novas configurações étnicas baseadas em uma identificação compartilhada.

Desde as independências na América Latina e durante o processo de construção dos Estados nacionais de inspiração européia, registraram-se processos de etnogênese protagonizados por diferentes populações. Essa foi uma época marcada pela expansão das burguesias crioulas sobre as terras indígenas remanescentes, dando lugar a numerosas rebeliões e insurreições que incidiram na transformação do panorama étnico herdado do período colonial. Assim, a maciça insurreição maia de Yucatán, conhecida como a Guerra das Castas (1847-1853), gerou uma nova organização étnica maia macehual, proveniente do mesmo grupo etnolingüístico, mas dele separada em termos políticos e de identidade, constituída por descendentes dos re- 
beldes que se refugiaram nas selvas orientais por mais de um século e meio (Bartolomé e Barabas 1977).

Por outro lado, as alianças militares formadas para se oporem a essa "segunda conquista" geraram a unificação política de sociedades compostas de faixas ou segmentos autônomos, como os Mocovíe da Argentina, os Yaqui e os Seri do México, os Nivaklé do Paraguai ou os Mapuche do Chile e da Argentina ${ }^{3}$. Essas alianças possibilitaram um comportamento e uma identificação coletiva em sociedades cultural e lingüisticamente afins, mas social e politicamente diferenciadas. Ou seja, geraram uma etnogênese, e ao produzirem um novo sujeito coletivo previamente inexistente como tal, embora potencialmente contido em uma configuração cultural. Vemos então que o mito da existência na América Latina, no passado e no presente, de sociedades "puras", dotadas cada uma de uma cultura específica e singular, é um tanto enganoso e tem sido criticado com base em distintos pontos de vista, assim como o fez Boccara (2000) ao insistir na flexibilidade e na adaptabilidade dos grupos indígenas, cuja lógica política e social incluía uma abertura às relações interculturais.

Nesse sentido, a etnogênese apresenta-se como processo de construção de uma identificação compartilhada, com base em uma tradição cultural preexistente ou construída que possa sustentar a ação coletiva ${ }^{4}$. Em outro ensaio (Bartolomé 2000a), salientei que a lógica econômica e sociorganizativa tradicional das sociedades caçadoras, baseadas nos processos de fissão e fusão de bandos de caça e coleta, não era propícia para o estabelecimento de associações muito maiores que as geradas pelos grupos parentais estendidos em uma faixa territorial. Tampouco as sociedades de linhagens dispostas em clãs territoriais, como a Mapuche - cuja lógica associativa foi parcialmente substituída pelo desenvolvimento de coletividades residenciais - eram dotadas de uma organização além das chefaturas e dos laços lingüísticos e culturais compartilhados. A mesma ausência de uma noção definida de coletividade étnica pode ser aplicada às famílias extensas ampliadas $\left(t y^{\prime} y\right)$ ou que constituem as unidades de produção, residência e culto guaranis. Também as numerosas comunidades aldeãs dos pastores e agricultores mesoamericanos e andinos, com tendencialidades autônomas, só manifestavam uma identificação compartilhada quando se aliavam entre si ou eram incorporadas a uma unidade política abarcadora. É que a mútua identificação de uma série de coletividades, ainda que lingüística e culturalmente afins, resulta sempre da presença de uma organização política unificadora ${ }^{5}$.

Não existiam no passado, portanto, as "nações" Wichí ou Toba do Grande Chaco, Mapuche do sul dos Andes, Aymara do planalto boliviano, Nahua do México ou Tupi-guarani das florestas tropicais, tal como as entenderiam as 
óticas nacionalistas oitocentistas, mas sim grupos etnolingüísticos internamente diferenciados em grupos étnicos organizacionais, entendidos como comunidades identitárias exclusivas, que podiam não ter maiores relações entre si. Por isso, os rótulos étnicos generalizantes, ao delimitarem etnias classificatórias, como Guarani, Quéchua, Maia, Zapoteco, Toba ou Mataco, sobretudo eram, e são, atribuições identitárias externas em vez de etnônimos próprios, embora agora mesmo os indígenas possam recorrer a eles para se designarem como coletividades inclusivas e exclusivas. Já assinalei, em outra oportunidade, que uma das lutas das sociedades nativas do presente é a de se constituírem como coletividades, como sujeitos coletivos, para poderem se articular ou se confrontar com seus Estados em melhores condições políticas, já que a magnitude numérica e as demandas compartilhadas aumentam suas possibilidades de êxito. Trata-se da criação de um novo sujeito histórico, de uma etnogênese cuja cristalização poderíamos chamar de "Povos Indígenas", entendendo-os como "nações sem Estado" (Bartolomé 2000).

\section{As etnogêneses do presente}

Há alguns anos, antropólogos, parcela da opinião pública e classes políticas envolvidas na questão vêm reagindo com certa surpresa em face dos atuais processos de etnogênese, como se esses fossem um elemento inédito ou mais um produto da globalização, à qual se atribuem até as mudanças climáticas, ou ainda um evento derivado da pós-modernidade, que confunde filosofia com etnografia. A nova visibilidade política obtida pelos povos indígenas nas últimas décadas faz com que os processos pelos quais eles passam sejam objeto da reflexão, algo desconcertada, dos responsáveis ao decretarem que a "modernidade" era o fim da etnicidade, ou que esta era uma "contradição secundária" das sociedades de classes. No entanto, os povos nativos sempre estiveram ali, não como fósseis viventes do passado, mas sim como sujeitos e participantes da história, como sociedades dotadas de dinâmicas próprias que transcendem as percepções estáticas. Para os etnógrafos de campo e para as populações regionais, essa presença étnica nunca esteve realmente oculta, a não ser por sua ausência no discurso acadêmico e político que até recentemente não havia reparado nela. É que subjacente a este desconcerto diante da etnicidade está a reificação do Estado-nação, ao qual se atribuía a capacidade de produzir uma desejada homogeneização cultural e para o qual as lealdades étnicas são percebidas quase como uma traição à pátria ${ }^{7}$.

O "mito da miscigenação", entendido como a realização generalizada de uma síntese racial e cultural em toda a América Latina, alimentou também 
a ideologia conforme a qual os índios tinham desaparecido e agora todos os habitantes de cada Estado eram homogêneos graças a esse processo. Um dos Estados que mais nutriram tal fantasia em seu imaginário social foi o México, cujos intelectuais e políticos elevaram a miscigenação em nível de "raça cósmica". No entanto, quase todos os demais países, com a provável exceção dos detentores de áreas amazônicas cujos habitantes nativos não são facilmente traduzíveis ao "nós" nacional, fizeram da imagem de uma síntese conquistada parte do imaginário político nacional. Assim, a revolução boliviana de 1952 decretou que os Aymara e os Quéchua passariam a ser chamados de "sindicalistas campesinos", tentando tornar compatível a lógica de um proletariado rural com a dos Ayllu andinos. Na década de 1970, o governo populista do Peru impôs aos nativos a denominação de "camponeses", procurando superar o estigma lançado sobre o "índio". A Argentina declarou-se "branca" desde sempre, folclorizando as culturas nativas e declarando-as parte do passado da nação, embora tenha população indígena maior que a do Brasil, país onde, contraditoriamente, acredita-se viver uma grande quantidade de nativos amazônicos. Por sua vez, os revolucionários sandinistas minimizaram a presença étnica na Nicarágua, onde supostamente "não havia índios verdadeiros" (Gould 1998:274) devido à miscigenação. Em El Salvador, era comum afirmar-se não existirem índios, apesar de chegarem a centenas de milhares as pessoas que se identificavam como tal e, para surpresa daqueles que procuravam torná-los invisíveis, terem formado, na década de 1980, a Asociación Nacional Indígena del Salvador ${ }^{8}$ - embora apenas um punhado delas fale línguas nativas e se auto-identifique por meio de critérios históricos e residenciais (Chapin 1996). Sem pretender multiplicar os exemplos, pode-se presumir que a atual visibilidade étnica provém também de uma mudança ideológica por parte das populações indígenas e cuja conseqüência foi a reformulação da "cegueira ontológica" construída pelas ideologias nacionalistas estatais.

Em alguns casos, a etnogênese pode ser o resultado indireto e não planejado de políticas públicas específicas. Registram-se muitos processos dessa natureza na América Latina e qualquer enumeração omitiria, sem dúvida, vários casos não documentados. Todavia, naqueles que são conhecidos é factível identificar elementos comuns. Trata-se da dinamização e da atualização de antigas filiações étnicas às quais seus portadores tinham sido induzidos ou obrigados a renunciar, mas que se recuperam, combatentes, porque delas se podem esperar potenciais benefícios coletivos. Em certas oportunidades isso se deve à desestigmatização da filiação nativa, mas freqüentemente também às novas legislações que conferem direitos antes negados, como o acesso à terra ou a programas de apoio social ou econômico. 
AS ETNOGÊNESES: VELHOS ATORES E NOVOS PAPÉIS NO CENÁRIO CULTURAL E POLÍTICO

Um caso que pude acompanhar de perto é o dos Ixcateco de Oaxaca, México. Trata-se de uma antiga unidade política pré-hispânica reduzida, pelas enfermidades coloniais, a uma única localidade e obrigada a proceder a uma rápida renúncia lingüística como conseqüência da migração de trabalhadores e de políticas castelhanizadoras compulsórias das primeiras décadas do século XX (Bartolomé 1996). Depois da rebelião do Exército Zapatista de Libertação Nacional em Chiapas, tanto o governo federal quanto o estadual começaram a incrementar suas políticas de apoio às comunidades indígenas, tentando evitar a propagação do ímpeto insurrecional. Como resultado, muitos povoados que haviam aparentemente renunciado à sua condição étnica reassumiram-na para serem beneficiários de tais programas. Entre eles estavam os Ixcateco, cuja última dezena de falantes da língua própria passou a ser exibida como emblema da identidade local e acabou recrutada por uma agência educativa - a mesma que antes contribuíra para o seu deslocamento - a fim de ensinar o esquecido idioma a seus conterrâneos (Barabas e Bartolomé 1999).

Outro caso recente tem como protagonistas os chamados Chocho (ngigua), coletividade da qual restam apenas poucas centenas de habitantes, mas com cuja cultura vários milhares se identificam, tanto em termos históricos quanto pela residência em povoados de tal tradição (Barabas e Bartolomé 1999). Diferentes localidades ngigua começaram um processo de reatualização étnica, expresso nas tentativas para recuperarem a língua em ambiente escolarizado, com a elaboração de alfabeto próprio, a publicação de materiais didáticos em seu idioma e a realização de múltiplas assembléias e eventos, assim como a mudança dos topônimos nahuas locais pelas remotas denominações, a fim de renomear o antigo território com as velhas e pouco lembradas palavras (Barabas e Bartolomé 2003).

No outro extremo do continente, na supostamente "branca" Argentina, os Tonocoté, Selk'nam, Huarpe, Mocovíe e Diaguita, considerados extintos, bem como os Kolla ${ }^{9}$, aparentemente desetnizados, ressurgem em função do amparo da nova legislação que reconhece os direitos das minorias (Bartolomé 2004). O tema tem gerado certa polêmica sobre o que se considera ser um grupo étnico, em especial no caso huarpe, cuja população atual não parece guardar correspondência física nem histórica com a ancestralidade reivindicada e é considerada um grupo de interesse que pretende ter acesso a terras outorgadas pela Constituição a comunidades indígenas (García 2002). No Paraguai, os guaná, coletividade arawak cujos últimos representantes eu supunha ter entrevistado há mais de 30 anos (Bartolomé 1969), estão agora reaparecendo no mapa étnico do Chaco Boreal graças ao trabalho de um grupo de apoio à recuperação cultural composto pelos chamados Maskoy, 
falantes de enlhet, língua aparentada à dos guaná, que os vem motivando a recuperar um legado que os dispersos membros dessa etnia assumiam como definitivamente perdido (Unruth e Kalisch 1999).

Na Colômbia, em 1993, centenas de Kankuano da Serra Nevada de Santa Marta, qualificados como totalmente "aculturados" 40 anos antes e até aquele momento desaparecidos, ressurgiram num congresso indígena empunhando a Constituição de 1991 que permite a criação de entidades territoriais indígenas. O direito a tais entidades não é apenas reivindicado pelos Kankuano: também lhes é reconhecido pelos outros três grupos da Serra Nevada (Gros 2000). De fato, uma intelectual kankuano escreveu um significativo ensaio no qual destaca os traços culturais definidores de seu povo e argumenta que os sincretismos e a aculturação são, na verdade, eventos de resistência que possibilitaram a reprodução e a reconstituição cultural da coletividade indígena (Ochoa Arias 2005).

Outro processo de etnogênese colombiano é protagonizado pelos Yanacona do maciço central, etnia constituída por membros de diversos grupos deslocados, na época colonial, da chamada tierra caliente* e que, em 1992, criaram o Cabildo Mayor del Pueblo Yanacona (ou Associação Maior do Povo Yanacona), manifestando um desejo de unidade étnica avalizada pela busca de sentidos culturais expressos por meio do desenvolvimento de uma complexa cosmologia de características andinas que, progressivamente, vai dotando a identidade yanacona de uma base cultural, ainda que seus integrantes já não falem a língua quéchua (Zambrano 2000). A Venezuela também não é alheia à etnogênese. Ao contrário, o fenômeno multiplicou-se com tanta intensidade nos últimos anos que já se fala dos neo-chayma, dos neo-kariña ou dos neo-guayqueríe, como grupos que se supunha estarem desaparecidos ou "aculturados" e que, agora, ressurgem no cenário nacional com reivindicações econômicas, sociais e territoriais definidas, baseadas em sua condição étnica (Arvelo-Jimenez 2001).

No desértico norte do Chile, que muitos consideram livre do "problema indígena" representado pelos combativos Mapuche do sul, fazem-se agora presentes os Atacama, antes considerados praticamente desaparecidos ou "assimilados". Não se sabe exatamente quantos são, já que o critério de censo lingüístico é irrelevante, uma vez que perderam sua língua materna, o kunza. Todavia, segundo o censo de 2002, cerca de 14.000 pessoas reivindicam sua identificação com uma coletividade social pré-hispânica, cujo aspecto físico pode estar presente nos rostos atuais, mas que não é suficiente para

* [N.T.] Regiões de temperaturas mais elevadas e com até 1.000 metros de altitude e que correspondem a mais de $80 \%$ do território colombiano. 
AS ETNOGÊNESES: VELHOS ATORES E NOVOS PAPÉIS NO CENÁRIO CULTURAL E POLÍTICO

circunscrever as fronteiras da etnia. Sem dúvida, influíram na manutenção das fronteiras étnicas as históricas relações de trabalho etnoclassistas (Rivera Flores 1997) e a aceitação comum do estigma atribuído à condição étnica - mas também uma memória que propõe a ascendência incaica, embora em realidade os Atacama tenham sido um povo subordinado ou intimamente relacionado aos Inca nas décadas anteriores à invasão espanhola. Desenvolveu-se uma ideologia indianista pan-andina de viés katarista** e recorreu-se à arqueologia e à etnohistória para legitimar as reivindicações e fundar uma identificação coletiva que transcendesse as filiações comunitárias (Rivera Flores 2004).

Na tentativa de superar seu estigma, os Atacama não procuram agora renunciar à sua identidade, mas assumi-la como um novo tipo de cidadania que aspira aos direitos assegurados pela legislação às coletividades étnicas (Gundermann Kröll 1997). O governo chileno apontou sua estratégia jurídica para o sul, para a Araucanía, mas também gerou impacto, involuntariamente, no norte. Ademais, nessa paisagem lunar salpicada de produtivos oásis, ressurgiu também, e com intensidade, a presença dos Aymara, sustentada por um setor desse grupo etnolingüístico boliviano que, em decorrência da Guerra do Pacífico, acabou incluído nas fronteiras estatais chilenas, conjugando assim o estigma étnico com o de uma "condição estrangeira" à qual se deveria renunciar por meio da assimilação plena à chamada identidade nacional chilena ${ }^{10}$. Hoje os Aymara recorrem às suas tradições culturais andinas, como a reciprocidade e a solidariedade comunitárias, junto a uma memória fragmentada, mas viva, para conseguirem reproduzir-se como tais em um meio marcado pela hostilidade e pelo racismo (Gonzáles Cortez 1997).

Muitas vezes, a sobrevalorização de uma noção substancializada da aculturação - não atenta às ideologias étnicas - influiu na aparente extinção de alguns grupos. Um caso ilustrativo, já abordado por vários pesquisadores, é o dos Cocama. Por volta de 1970, o antropólogo D. Lathrap qualificou de ex-cocama uma população de ascendência guarani da Amazônia peruana, habitante do povoado de Juancito, que se ofendia quando classificada como "indígena". Em um estudo mais recente sobre o tema, Gow (2003) trata da estigmatização identitária em conseqüência da qual as pessoas de ascendência indígena se apresentavam como "mestiços" brasileiros, identificação legitimada tanto pelo discurso regional quanto pelo estatal. Ao analisar a lógica onomástica indígena, Gow advertiu: os que se consideram ex-cocama

** [N.T.] O adjetivo remete a Tupac Katari, ou Julián Apasa, executado em 1781 pelas forças coloniais na Bolívia, depois de dirigir uma rebelião indígena que sitiou duas vezes La Paz. 
são aqueles que têm sobrenomes indígenas, mas não reconhecem a si mesmos como membros de uma comunidade "tribal" similar às de outros grupos amazônicos, embora não renunciem à filiação étnica - ou seja, trata-se de uma questão de denominação, já que os Cocama continuam existindo sob outra designação que pressupõe uma reformulação da ideologia residencial e identitária.

Este ensaio, um dos poucos a explorarem as lógicas internas nativas e não só as provenientes do contexto local, abre interessantes possibilidades para a análise de aparentes etnogêneses que não seriam senão o reaparecimento da mesma sociedade com outro rosto cultural ou com outro nome. No lado brasileiro, contam-se agora mais de 2.000 Cocama no rio Solimões, cujo ressurgimento étnico é questionado pela população local, por grupos nativos vizinhos e por funcionários indigenistas, que não os consideram "índios verdadeiros" e negam legitimidade às suas reivindicações territoriais (Mantoanelli 2004). Em outro estudo recente, Petesch (2003) aprofundou o tema identitário, observando que os Cocama, tanto no Peru quanto no Brasil e na Colômbia, identificam-se para o exterior alternativamente como indígenas e não-indígenas, conforme o contexto de inserção dos modelos identitários locais impostos pelas diferentes sociedades regionais. Contudo, "o cocama", com variados conteúdos, manifesta-se agora em cinco organizações indígenas no Peru e uma no Brasil e, pelo menos até o momento (2004), nenhuma na Colômbia.

No mesmo sentido, Porto Alegre (1998) questionou a condição de "desaparecidos" atribuída a numerosos grupos do nordeste do Brasil. A transfiguração cultural - a adoção de numerosos traços materiais e simbólicos da sociedade envolvente - não implica o enfraquecimento automático das identidades étnicas, mas sua reformulação em um novo contexto que ela qualifica como "cultura do contato". Todavia, a antropologia e as políticas públicas tenderam a esquecer, ou a não reconhecer, essas presenças étnicas não mais redutíveis aos arquétipos indígenas nacionais representados pelas aldeias amazônicas. Assim, as etnogêneses nordestinas não foram senão a emergência política de identidades étnicas antes irreconhecíveis para o exterior devido à transfiguração cultural. A respeito desta questão, Arruti (1997) propôs que as classificações das populações nativas responderam historicamente às vontades políticas de domínio e controle social e que, portanto, seu ressurgimento contestatário corresponde ao desenvolvimento de um novo tipo de sujeito político orientado a enfatizar sua alteridade para ser reconhecido como tal. Assim, as relações das comunidades atuais com as do passado produzem-se por meio da seleção e da recriação de aspectos da memória e de traços culturais emblemáticos, capazes de atuarem como sinais 
AS ETNOGÊNESES: VELHOS ATORES E NOVOS PAPÉIS NO CENÁRIO CULTURAL E POLÍTICO

externos de reconhecimento entre aquelas instâncias de poder que declararam sua extinção. Como em outros casos, a esses processos de emergência identitária não são alheias as legislações que garantem direitos especiais às comunidades nativas, mas o fato de que estas não tenham se manifestado antes como tal não deriva de sua não-existência, mas de sua estigmatização. Entretanto, a construção ou a reconstrução das identidades orientada para certos fins e, por conseguinte, suscetível de ser qualificada como instrumental não se esgota nesta qualificação. Afinal, pressupõe processos sociais de extrema complexidade que nos obrigam a tentar entender as ideologias da ocultação e as do afloramento, tal como as retomarei mais adiante.

Embora os exemplos possam multiplicar-se, prefiro descrever mais extensamente um desses casos, a cujo relato não resisto. Há alguns anos, em 1986, quando eu era professor convidado da Universidade da Bahia, coubeme acompanhar uma equipe de colegas em seus trabalhos com os indígenas Quirirí e Tuxá do nordeste brasileiro. Ao chegar ao povoado de Rodelas, no vale do rio São Francisco, reparamos em um cartaz da Fundação Nacional do Índio (FUNAI), segundo o qual, por se tratar de uma "aldeia indígena", a entrada no lugarejo restringia-se a uma de suas ruas. Transgredimos a restrição e caminhamos entre construções de alvenaria habitadas por uma população de pescadores mulatos desfrutando o frescor da tarde, vendo televisão sentados à porta de casa. Em seguida, entrevistamos as autoridades locais, constituídas pelos cacique e pajé (termo tupi para os especialistas religiosos) que, em realidade, atuavam como líderes comunitários municipais. Eles nos disseram pertencer à "nação tuxá, tribo troká, índios de arco, flecha e mabaraká" - curioso mote que aludia à sua identificação étnica. O aspecto físico desses Tuxá era predominantemente mulato ou "caboclo". Ninguém falava língua indígena: todos se expressavam no português típico do nordeste brasileiro. Alguns homens e crianças tinham pele e olhos claros, embora suas mulheres fossem em geral mulatas. A aldeia estava ameaçada por um processo de realocação forçada, provocado pela inundação derivada da construção da represa de Itaparica, e todos nos fizeram saber de suas preocupações nesse sentido. Em especial, estavam angustiados porque a represa submergiria a Ilha da Viúva, em cujas terras férteis tinham alguns cultivos e onde, ademais, realizavam a exclusiva cerimônia do toré e a ainda mais secreta cerimônia "particular", vedada aos brancos. Ambas constituem seus rituais de reconstituição comunitária e nelas nossos colegas haviam percebido claras influências dos cultos afro-brasileiros.

A situação era algo estranha: encontrávamo-nos em um povoado de mulatos e caboclos que, embora vivessem como todos os demais camponeses e pescadores, não falassem uma língua nativa e tivessem adotado um cerimo- 
nial afro-brasileiro declaravam-se indígenas e tinham autoridades próprias cujos títulos pareciam não pertencer ao contexto. No entanto, a despeito das aparências, não se tratava de uma "farsa" étnica. Os Tuxá são descendentes de vários grupos aldeados pelos jesuítas no século XVII - provavelmente, grupos de idiomas distintos, motivo pelo qual recorreram ao português como língua geral. Posteriormente, passaram a abrigar muitos negros fugidos das fazendas. No século XX, a discriminação da qual eram objeto levou-os a solicitar a proteção da FUNAI para, assim, garantir certa estabilidade territorial. Com isso, alguns camponeses sem terra buscaram mulheres entre eles para terem acesso a um quinhão dessas terras (Násser e Cabral 1988). Apesar do deslocamento lingüístico e da transfiguração cultural, os Tuxá continuavam a se perceberem e a serem percebidos pela população local em termos étnicos - ou seja, as fronteiras étnicas se haviam mantido e tinham desenvolvido processualmente as identidades contrastantes. Alguns colegas pensavam que a manutenção da identidade estava relacionada aos direitos territoriais que lhes outorgava a FUNAI, muito embora tenham sido eles, como comunidade preexistente e com capacidade de ação coletiva, a solicitar a proteção das autoridades indigenistas. Apesar de quase completamente esquecidos do mapa étnico da Bahia, os Tuxá estavam presentes como tal e reivindicavam seus direitos centenários ante a construção da represa.

Talvez seja possível também qualificar de etnogênese os processos atuais de recuperação demográfica de grupos étnicos que estavam, ou eram considerados, em vias de extinção devido ao escasso número de sobreviventes. Apesar da precariedade das atuais condições de subsistência da maior parte da população indígena da América Latina, em muitos países as políticas sanitárias e assistenciais desenvolvidas pelos Estados e por organizações internacionais na segunda metade do século XX geraram um substancial incremento na esperança de vida dos grupos nativos e de outros setores marginalizados. Talvez mais que de etnogênese, poderíamos falar nesse caso de renascimentos, protagonizados por populações que conseguiram, ou estão conseguindo, recuperar suas magnitudes demográficas.

As estatísticas seriam demasiado cansativas para o leitor, mas vejamos alguns casos: um da Amazônia e dois da Mesoamérica. Quando, em 1952, a etnógrafa viajante Wanda Hanke visitou os Chacobó, caçadores e coletores da família lingüística pano e habitantes das florestas do oriente boliviano, calculou seu número em não mais de uma centena de pessoas, às quais se teria de adicionar uns poucos ramos não contatados (1956). A situação não era muito diferente há 20 anos: em 1985, registraram-se 300 integrantes dessa etnia. Contudo, para surpresa das autoridades e dos pesquisadores, o total chegou, em 2004, a 1.090 pessoas, que não só reivindicavam sua 
AS ETNOGÊNESES: VELHOS ATORES E NOVOS PAPÉIS NO CENÁRIO CULTURAL E POLÍTICO

identidade, mas também parte do território tradicional onde os Chacobó viviam, itinerantes, na região do Beni (Iniciativa Amazónica 2004). Outro caso foi observado no estado mexicano de Oaxaca: em 1930, a população dos 14 grupos etnolingüísticos locais ascendia a cerca de 520.000 pessoas, mas no ano de 2000 ultrapassava 1.300.000 (Barabas e Bartolomé 1999). E se nós voltarmos a atenção para a área maia, encontraremos mais um exemplo: a expectativa de vida de um maia yucateco, em 1930, era de apenas 23,35 anos, em contraste com o índice atual, superior aos 70 anos (Bartolomé 1988) - motivo pelo qual não se deve estranhar que, naquele ano, esse grupo étnico reunisse 320.000 pessoas e, agora, alcance quase um milhão. Não é necessário multiplicar relatos ilustrativos, acessíveis nos distintos países a partir de releituras da sempre duvidosa informação estatística referente aos grupos étnicos. Indubitavelmente, a recuperação demográfica indica que os Povos Originários não são apenas o passado e o presente da América Latina, mas também parte constitutiva de seu futuro.

\section{A etnogênese em perspectiva}

O tema não é novo para a reflexão antropológica e, sem dúvida, a obra de Roosens (1989) constitui uma contribuição significativa sobre a questão, embora Sider (1976) já houvesse recorrido ao termo, definindo-o como o oposto ao etnocídio. Para Roosens, a etnogênese, em uma perspectiva contemporânea, remete ao fato de que a etnicidade não representa um dado imutável ou um aspecto essencial de um grupo, mas pode ser modificada, recriada e inclusive construída ou reconstruída de acordo com as necessidades dos atores. Para este autor, tal processo insere-se na competição por recursos - conclusão amparada em uma perspectiva instrumentalista e apoiada por uma série de estudos de caso que demonstrariam as vantagens estratégicas de se recorrer ao discurso identitário. No entanto, sua proposta não é mecanicista, já que Roosens deixa claro tratar-se de um longo processo por meio do qual um grupo de seres humanos constrói sua realidade (1989:20). Sublinha, ademais, o fato de não se poder negar que um grupo tenha ancestrais, um passado, uma cultura, origens biológicas compartilhadas, ou que viva em certo lugar, em algum espaço físico. Porém, quais foram esses ancestrais, como ocorreu esse passado, que cultura se transmitiu, que relação tiveram com os vizinhos ou se o território lhes pertenceu desde sempre depende dos desejos do grupo em questão (1989:160).

Para João Pacheco de Oliveira Filho (1998), por sua vez, o conceito de etnogênese inclui tanto o surgimento de novas identidades quanto a rein- 
venção de etnias já conhecidas. Conforme este autor, a situação colonial instaura novas relações entre as sociedades indígenas e seus territórios e leva a transformações sociais e culturais, uma vez que a territorializaçao ${ }^{11}$ supõe um processo de reorganização social radical. Tal reorganização implicaria: 1. a criação de uma nova unidade sociocultural mediante o estabelecimento de uma identidade étnica diferenciadora; 2. a constituição de mecanismos políticos especializados; 3 . a redefinição do controle social sobre os recursos ambientais; e 4. a reelaboração da cultura e da relação com o passado. Sua proposta tem como base fática os grupos indígenas do nordeste brasileiro, mas creio ser pertinente também para aquelas coletividades nas quais a colonização e o aldeamento supuseram uma reformulação da relação com o meio, transformando seus padrões de assentamento e mobilidade. Assim, por exemplo, as sociedades de tradição seminômade do norte do México, como seri, yaqui, mayo, guarihio, guarihó, pima, o'odham ou rarámuri, foram nucleadas, primeiro pelos missionários e depois pelas autoridades estatais, em "tribos" às quais se pretendeu dar o caráter de comunidades, seguindo o modelo agrícola do sul do país, ainda que tal sistema organizativo fosse desconhecido dos bandos compostos de caçadores, coletores e horticultores. Nesse sentido, os atuais povos indígenas do norte mexicano são o produto de processos impostos de territorialização, cujos resultados foram etnogêneses baseadas na estruturação de unidades étnicas que reuniram membros de agrupamentos etnolingüísticos internamente diferenciados.

Embora existam importantes aportes aos processos históricos e contemporâneos de etnogênese na obra coletiva editada por Hill (1996), um interessante ensaio de Antonio Pérez (2001) procura abordar o tema de maneira comparativa. Este autor cunha inclusive uma tipologia inicial, na qual distingue, entre outras, as etnias reconstruídas, ou seja, aquelas que perderam há pouco suas bases culturais identitárias mas que mantêm uma continuidade territorial, parental ou histórica, e as etnias ressuscitadas, cuja relação com o passado provém em parte da memória e em parte da literatura existente sobre o grupo. Aqui, sugiro utilizar o conceito de maneira ampliada, para designar também os processos de atualização identitária de grupos étnicos que enfrentaram profundas mudanças de transfiguração étnica, podendo ser considerados praticamente extintos e cuja emergência contemporânea constitui um novo dado para a reflexão antropológica e para as políticas públicas em contextos multiculturais. Interessa-me inclusive relacionar a etnogênese aos processos de revitalização étnica e unificação política dos grupos etnolingüísticos historicamente estruturados como sociedades polissegmentárias acéfalas, isto é, carentes de uma organização política generalizada, que passa a ser agora construída ou reconstruída. Trata-se de uma referência às atuais 
AS ETNOGÊNESES: VELHOS ATORES E NOVOS PAPÉIS NO CENÁRIO CULTURAL E POLÍTICO

dinâmicas etnopolíticas que propõem a configuração ou a reconfiguração de sujeitos coletivos definidos em termos étnicos, protagonizadas por grupos etnolingüísticos que perderam, ou nunca tiveram, a experiência de uma mobilização conjunta em prol de objetivos compartilhados. Processos desse tipo também foram designados como retribalização, reetnificação, atualização identitária ou recuperação cultural. No passado, os messianismos foram, por vezes, responsáveis pela reestruturação ou construção comunitária de coletividades humanas internamente diversificadas, mas ideologicamente unidas ante as imposições coloniais (Barabas 1989). No presente, embora os aspectos socioreligiosos possam ser levados em conta, parece tratar-se mais de processos de natureza etnopolítica, ou seja, mobilizações seculares orientadas pela confrontação com o exterior, mas alimentadas por sua lógica interior.

Sugiro, então, procurarmos entender as etnogêneses contemporâneas não só em termos da articulação dos grupos étnicos com o Estado nacional, mas também em relação com as dinâmicas internas das sociedades nativas. Como todo fato no interior de um sistema interétnico, uma parte não é compreensível sem a outra, mas as dinâmicas internas não se esgotam nem se reduzem exclusivamente aos determinantes externos. Do contrário, certo estímulo exterior produziria sempre a mesma resposta, como se as culturas indígenas fossem idênticas umas às outras. A etnogênese ${ }^{12}$, entendida como construção ou reconstrução identitária, constitui tema sumamente complexo e não se presta a uma interpretação unívoca. Nesse sentido, creio, devemos afastar-nos um pouco das tradicionais explicações baseadas nas perspectivas das "comunidades imaginadas" de Anderson (1993) ou da "invenção da tradição" cunhada por Hobsbawm e Ranger (1983) - formulações propostas para analisar processos estatais de construção nacional e cuja aplicação ao caso das culturas indígenas, carentes dos sistemas comunicativos e dos aparatos de homogeneização política e ideológica dos Estados, pode ser duvidosa ou insuficiente.

Em alguns casos, a surpresa antropológica ante as aparentes etnogêneses, que na verdade supõem, freqüentemente, a manifestação pública de coletividades "que já estavam ali", provém da influência teórica ou subteórica do paradigma da aculturação: "se não parecem mais indígenas, é porque já não são indígenas"13. No entanto, há quase 70 anos, os ilustres autores do Memorandum of the Study of Acculturation já haviam advertido que "aculturação" não era equivalente a "assimilação", embora aparentemente não se tivesse dado suficiente atenção ao significado profundo de ambos os conceitos (Redfield, Linton e Herskovits 1936). Mesmo sem exibirem uma cultura material distintiva, sem falarem línguas indígenas, vestindo-se como os ocidentais e partilhando de sistemas culturais aparentemente não muito 
diferentes dos característicos dos Estados-nação nos quais estão contidos, certos grupos reivindicam uma identificação própria - indício de que a idéia de aculturação, entendida como adoção de traços culturais externos, carece de capacidade explicativa em relação às identidades étnicas. A questão é ter-se considerado que "o hábito faz o monge": partia-se da percepção do exterior para entender o interior, fechavam-se os olhos à impossibilidade de reduzir a identidade a formas culturais específicas, passíveis de mudarem com o tempo sem que a identificação desaparecesse, embora recorressem a outros referentes culturais, próprios ou apropriados, para a sua sustentação. Nesse sentido, devemos recordar, a língua não constitui o único indicador diacrítico da identidade étnica ${ }^{14}$. É possível recorrer a um vasto conjunto de elementos históricos ou culturais para afirmar a condição de indígena e definir o pertencimento de seus protagonistas. Os traços culturais que dão substância à identidade e lhe servem de argumento estão submetidos à historicidade que lhes é própria. Pode-se ser mapuche e engenheiro atômico, mixteco e antropólogo ou toba komlek e arquiteto.

No entanto, a etnogênese surpreende aqueles que vêem operários, artesãos, profissionais ou empregados públicos manifestando-se em termos étnicos e recorrendo, por vezes, a indicadores visíveis de filiação étnica, como penas ou vestimentas, freqüentemente considerados em termos performativos, de acordo com a terminologia da moda ${ }^{15}$. Nos processos de afirmação étnica, e em especial nos encontros interétnicos, é comum recorrer-se a emblemas identitários, isto é, a traços materiais ou ideológicos, próprios ou apropriados, que indiquem explicitamente a identidade de seus possuidores; assim, as roupas ou o artesanato (ponchos, faixas, sombreiros etc.) são ressignificados e passam a deter um valor emblemático, ausente em seu uso cotidiano (ou na falta do uso). Este aspecto externo, esta exposição pública da identidade costuma confundir os observadores, que o vêem somente como um exibicionismo étnico interessado. E desta percepção não está ausente a perspectiva instrumentalista da identidade, com sua duvidosa sorte de ter recrutado uma grande quantidade de adeptos. Aqueles para quem a etnicidade - a afirmação contestatória da identidade - é considerada apenas um meio para obter determinados fins devem recordar que toda a ação humana é motivada por algum tipo de interesse específico. Todavia, o interesse não implica obrigatoriamente motivações espúrias. Podem-se mobilizar recursos lingüísticos ou culturais para alcançar determinados propósitos, porque tais recursos de alguma maneira existem e não necessariamente estão sendo inventados naquele momento. A manipulação da identidade étnica não inclui obrigatoriamente a mentira ou a falsificação, embora indubitavelmente possa ser um recurso para a ação. 
AS ETNOGÊNESES: VELHOS ATORES E NOVOS PAPÉIS NO CENÁRIO CULTURAL E POLÍTICO

De acordo com as observações feitas até aqui, o fato de que a etnogênese possa servir em determinada conjuntura para obter algum recurso crucial, como a terra, não pressupõe a configuração da coletividade étnica exclusivamente para esse fim ${ }^{16}$. Assim, em suas pesquisas sobre etnogênese no Suriname, Whitehead conclui que não se pode distinguir entre o primordialismo ou o instrumentalismo na configuração das novas identidades ameríndias resultantes do processo de colonização (1996:34). Não parece compatível com o reducionismo instrumentalista o fato de que a maior parte dos grupos protagonistas desses processos de etnogênese tenha gerado uma grande quantidade de reivindicações relativas à revitalização do antigo sistema cultural, como a educação bilíngüe, a retomada da cultura, a busca de velhas tradições, a formalização e a escrita de suas línguas etc. Um dos objetivos pode ser a obtenção de recursos, mas outro é a própria recuperação ou reconstrução da coletividade étnica de pertencimento.

O problema da lógica instrumental é a ausência, em seus horizontes, da valorização tanto das ideologias quanto dos afetos. As ideologias, capazes de construírem ou de mudarem mundos sociais, podem ser qualificadas de apelações ao imaginário, mas este corresponde, devemos lembrar, a uma dimensão da realidade que opera, e muitas vezes decide, sobre a vida e os destinos dos seres humanos. Trata-se de uma consciência possível, responsável por produzir determinado tipo de experiência existencial, podendo ser tão válida ou tão ilegítima quanto qualquer outra, mas que não deixará de existir só porque podemos desconstruí-la e remetê-la às suas origens históricas ou sociais. Da mesma maneira, a importância das emoções, da afetividade envolvendo a relação com um grupo que alimenta nossas expectativas objetivas e subjetivas foi minimizada pelo instrumentalismo, esquecendo-se que as pessoas podem chegar a extremos insuspeitos para defenderem um pertencimento social carregado de conteúdos afetivos. Um grupo étnico pode manifestar diversos tipos de tensões internas, sejam geracionais, sexuais ou de classe, mas tais tensões expressam a afetividade, positiva ou negativa, porém sempre intensa, característica das relações intragrupais marcadas pela proximidade. De fato, em vários dos processos de etnogênese com os quais tive contato direto (ngigua e lajpima do México, colla da Argentina, guaná do Paraguai), não se podiam determinar objetivos materiais específicos em disputa. Buscava-se tanto o fortalecimento das relações comunitárias ameaçadas por processos desintegradores, como a migração ou o deslocamento lingüístico, quanto fundamentalmente um recurso histórico à nova dignidade atribuída ao pertencimento étnico e baseada na intensidade das relações intra-étnicas e parentais, em oposição ao individualismo competitivo da sociedade estatal. 
No caso dos grupos etnolingüísticos que protagonizaram mobilizações etnopolíticas, ou seja, processos de organização interna e de luta política externa para obter determinados objetivos públicos, registra-se uma atualização exponencial da identidade coletiva, por vezes totalizadora a ponto de proporcionar sustentação ideológica a uma luta ativa e aos riscos vitais nela envolvidos. Trata-se de processos aos quais poderíamos nos referir como reetnização ou atualização identitária, derivada da experiência de participação política mediada pela influência das organizações etnopolíticas que contribuíram para dignificar o elemento étnico e para dar um sentido positivo à condição indígena. Também podem ser considerados etnogêneses, na medida em que aumentam a visibilidade política de sujeitos coletivos antes não tão aparentes em seus contextos estatais. Desenvolveram-se, assim, processos sociais de identificação que agora expressam a emergência de novas representações coletivas das identidades, assumidas como fundamentais por seus atores, em conjunturas históricas e contemporâneas nas quais se mantêm fronteiras entre grupos percebidos como diferentes.

A continuidade de um "nós" diferenciado advém também da existência de um grupo diverso para considerá-lo como "outros". A etnogênese propõe então um novo conteúdo e um sentido étnico, e ético, possível à diferenciação historicamente constituída. Nesses casos, as identificações não se "inventam", mas se atualizam, embora a atualização não recorra necessariamente a um modelo préhispânico já inexistente. Recupera-se um passado próprio, ou assumido como próprio, a fim de reconstruir um pertencimento comunitário que permita um acesso mais digno ao presente. Não se trata de uma invenção voluntarista, mas da expressão de um processo de produção simbólica concernente aos ideólogos e a todos os protagonistas. Nesse sentido, destacou Zambrano (2000:30), como conseqüência de seus relevantes estudos sobre a etnogênese dos Yanacona do maciço colombiano: "[...] Reafirma-se que a identidade de um povo, a etnicidade, não deve ser buscada na originalidade de seus traços culturais, mas na capacidade desse povo para gerar sentidos sociais e políticos que o unificam na luta para definir sua razão de ser como povo [...]". Este seria também o caso das religiões politeístas de possessão africanas, que se configuraram como religiões identitárias para a população negra brasileira (Agier 2001).

Construir uma ideologia coletiva em termos étnicos é uma empreitada cujos mecanismos encontram-se muito longe de estarem satisfatoriamente explicados. Em um de seus níveis, implica uma busca no passado para instituir uma nova relação com a realidade contemporânea. É uma tentativa de superar a deshistorização de que padecem os povos colonizados e reconstruir uma história, talvez fragmentária, mas tida como fundamental para recompor uma noção de coletividade, de comunidade histórica que deve se reencontrar com suas origens 
AS ETNOGÊNESES: VELHOS ATORES E NOVOS PAPÉIS NO CENÁRIO CULTURAL E POLÍTICO

confusas ou mitificadas a fim de reivindicar, em face dos outros e de si mesma, sua legitimidade passada e presente. Recuperar uma identificação estigmatizada pela discriminação social não é um processo pessoal ou social simples, isento de conflitos existenciais. Não se trata de um romantismo nostálgico, do qual só se esperam resultados gratificantes, mas da adoção deliberada de uma condição tradicionalmente subalterna, à qual se pretende imprimir uma nova dignidade. Isto pressupõe uma atitude contestatória e de desafio diante da sociedade majoritária em que se gestou o preconceito. Mas também envolve uma capacidade de simbolização compartilhada, por meio da qual antigos símbolos se ressignificam e adquirem o papel de emblemas, capazes de serem assumidos como tais por uma coletividade que encontra neles a possibilidade de construir novos sentidos para a existência individual e coletiva. Se esses símbolos produzem efeitos dinamizadores, se encontram uma caixa social de ressonância, é porque têm certo nível de presença em alguns dos portadores da memória coletiva local e que os legitimam ante seus círculos mais próximos. Como sabemos, a memória coletiva habitualmente não é tão coletiva. Em geral, os anciãos e alguns intelectuais orgânicos, cuja insatisfação com o presente leva a valorizar o passado, costumam ser os depositários dos dados capazes de "refrescarem" a memória coletiva. Esta reconstrução histórica e identitária tende a admitir distintos níveis de incongruências e de lacunas com relação a uma possível "verdade" historiográfica, já que não lhe importa tanto a coerência formal do relato ou da narrativa étnica construída, mas sua capacidade de se referir à vida social e de lhe dar um novo sentido.

Um aspecto da etnogênese observado entre os inuti, mas extensível a outros contextos, é a demora para que uma coletividade submetida a uma compulsão colonizadora perceba sua cultura como uma "coisa", uma "entidade" (Eriksen 1993:128). Leva-se muito tempo para entender que a perda de determinadas práticas e ideações sociais constitui parte de um todo passível de objetivação como uma cultura própria. Ultrapassando as discussões acadêmicas sobre o conceito de cultura, os indígenas conseguiram reconhecer o que se perde, recorrendo a uma denominação externa, mas igualmente válida. O processo de construção ou reconstrução identitária supõe assim um nível de reflexividade coletiva orientada para a valorização da história e da cultura compartilhada, em alguns casos mediada pela escrita. Na Mesoamérica e nos Andes, a produção escrita indígena alcança níveis de importância pouco reconhecidos pelas comunidades acadêmicas. Só no estado mexicano de Oaxaca, pude documentar nos últimos 30 anos a publicação de mais de 400 ensaios e livros antropológicos produzidos por indígenas, embora boa parte apareça em publicações locais de escassa circulação fora de círculos específicos (Bartolomé 2001). Muitos encerram argumentações contestatórias ou reivindicativas, mas vários outros também tentam uma abordagem não-ocidental de suas culturas, 
valendo-se inclusive da incipiente escrita nas línguas próprias, desenvolvida por uma crescente intelectualidade nativa. Muitas vezes os textos consultados pelos nativos são obras antropológicas, de pesquisadores profissionais, dedicadas à história ou à cultura do grupo e que adquirem assim uma dimensão política e social que originalmente não estava presente para seus autores. Nesse processo, as assépticas monografias etnográficas ou as obras históricas eruditas passam a constituir uma das bases da ideologia étnica, embora isso só seja possível se os leitores se identificarem a si próprios com os personagens dos quais falam os autores (Barabas e Bartolomé 2003). Não se trata, então, de uma falsificação nem de uma construção ilegítima por não estar mais presente nas práticas e na memória da sociedade, mas da busca de todas as estratégias possíveis de um grupo para se recuperar como coletividade distintiva.

Talvez se possa concluir assinalando que a etnogênese, para além de todos os fenômenos já expostos, destaca o dinamismo inerente às estruturas sociais, uma vez que tais estruturas não atuam sobre agentes passivos, mas sobre sujeitos ativos, capazes de modificá-las de acordo com seus interesses contextuais. Não creio que isso possa ser reduzido à perspectiva individualista da "escolha racional", mas ao desenvolvimento de sentidos coletivos da ação social cuja sustentação reside no recurso à inserção do indivíduo no grupo, ou seja, os fenômenos em questão são comunitários e comunitaristas. As coletividades que escolhem mudar as estruturas são constituídas por indivíduos, e entre eles pode haver alguns inovadores e revolucionários, mas sua ação desenvolve-se em um marco especial de receptividade cultural e, portanto, a escolha "racional" é social e não tanto pessoal. Os códigos simbólicos e de conduta dinamizados nas etnogêneses só podem ser efetivos caso coincidam com a experiência cultural da coletividade de participantes. Não se trata de uma continuidade cultural linear, mas de uma continuidade dos significados culturais da experiência, o que denota um substrato compartilhado de lógicas cognitivas e de interpretações da vida social. Se até poucos anos atrás a literatura não registrava processos de etnogênese, isso se devia, em parte, ao interesse dos antropólogos, mais voltado para a determinação de estruturas aparentemente coerentes nas culturas estudadas do que na dinâmica inerente a todas as estruturas. Os próprios sistemas simbólicos demonstram, através desses processos, sua capacidade não só de refletir a realidade, mas também de construí-la, uma vez que a identidade étnica, como estrutura ideológica, opera como um fator que informa a realidade ao determinar o desenvolvimento de tipos específicos de organizações sociais.

As etnogêneses também revelam como os processos de configuração étnica costumam ser acompanhados de uma vontade de associação política, na medida em que a construção comunitária supõe uma confrontação que envolve, ao mesmo tempo, a busca pelo fortalecimento da configuração social 
à qual se pertence para torná-la viável e projetá-la além de um determinado momento. E essa confrontação, ou articulação, geralmente recorre à dinamização da lógica política preexistente ou à sua reformulação e, inclusive, à sua criação para torná-la mais eficaz diante das necessidades de incrementar os mecanismos de mediação entre a coletividade étnica e a sociedade envolvente. Um caso verdadeiramente exponencial de etnogênese orientada para um novo tipo de participação política é o dos Aymara da Bolívia, grupo etnolingüístico cuja constituição como coletividade abarcadora, como grupo étnico identitário, chegou a níveis elevados por meio da confrontação com um Estado que não os representa (García Linera 2005). Assim se desenvolvem novas lideranças e estratégias políticas, talvez ausentes na experiência prévia do grupo - motivo pelo qual os Aymara são às vezes acusados de serem espúrios - mas agora relevantes para agirem em relação com os sistemas representativos próprios das chamadas democracias estatais. Cabe, nesse sentido, destacar que o caráter algo esquemático das normatividades estatais e internacionais sobre as definições do "étnico" faz com que, muitas vezes, a expressão nativa, ante essas instâncias, adquira um caráter fundamentalista ou "essencialista", em uma tentativa de se legitimar em face das instituições que podem apoiar suas causas ${ }^{17}$.

Por outro lado, e sem desvalorizar suas conseqüências etnológicas para a teoria social, a generalização dos processos de etnogênese na América Latina, e igualmente no resto do mundo, coloca-nos diante da evidência fática de que o pluralismo cultural e identitário representa uma característica inequívoca do presente. Sua dimensão política expressa-se por meio da presença de uma multidão de atores sociais envolvidos em disputas não só por recursos, mas também pelas mesmas dimensões de sentido que constituem as distintas estruturas de plausibilidade do sistema-mundo contemporâneo. Os rostos étnicos emergentes estão tão carregados de sistemas de sentido passados e atuais quanto de expectativas de futuros. A pluralidade da experiência humana não constitui um contexto histórico e cultural em processo de definitiva e irremediável homogeneização por obra das forças do mercado, operando agora no sistema mundial globalizado, mas um dado do presente, imprescindível para a construção política dos futuros possíveis.

Recebido em 27 de setembro de 2005

Aprovado em 02 de fevereiro de 2006

Tradução de Sérgio Paulo Benevides

Miguel Alberto Bartolomé é antropólogo, professor e pesquisador do Instituto Nacional de Antropologia e História do México (INAH - Oaxaca). E-mail: <barbar2@prodigy.net.mx> 


\section{Notas}

${ }^{1}$ Recorde-se da distinção de Lévi-Strauss entre sociedades "frias", reticentes à mudança, e sociedades "quentes", que induziam ou forçavam as mudanças nas primeiras. Embora as etnogêneses contemporâneas constituam processos mundiais, limitar-me-ei à sua análise na América Latina. Tal delimitação deve-se não só ao fato de ser este o âmbito em que tenho trabalhado e no qual tenho me relacionado diretamente com fenômenos desse tipo, mas também à semelhança das estruturas estatais, dentro das quais se inserem os grupos étnicos regionais que apresentam características recorrentes que facilitam a análise comparativa.

${ }^{2}$ A etnografia russa desenvolveu numerosas contribuições sobre o tema, pouco conhecidas devido aos problemas de tradução e divulgação. Conforme essa tradição, a língua e a continuidade territorial são fundamentais para a constituição de um ethnos. Um dos mais importantes autores dessa linha, Lev Gumilev, desenvolveu uma teoria algo eclética da etnogênese: para ele, trata-se de um processo da natureza, pelo qual a anthrosfera (biosfera humana) divide a si mesma como conseqüência de causas bioenergéticas, sem que a consciência étnica coletiva deixe de ser um fator determinante da etnogênese (Hryb 2000).

${ }^{3}$ Talvez um dos mais documentados estudos de processos de etnogênese desse tipo seja o de Boccara (2000) sobre os Mapuche do Chile. Conforme este autor, "o mapuche" começou a se formar por volta de 1500, com base na unificação política e militar dos Reche ("gente verdadeira" na língua mapudungun), em resposta à expansão do Império Inca. Essa mudança na estrutura social reche ampliou-se com a resistência à invasão espanhola e com a guerra contra o Estado chileno. A weichan (guerra) foi, assim, um dos fatores constitutivos do "mapuche".

${ }^{4}$ Em alguns casos, esses processos de estruturação étnica resultam de migrações interestatais cuja conseqüência é o desenvolvimento de uma coletividade diferenciada no seio de uma sociedade majoritária, da qual se distingue por razões lingüísticas, culturais ou religiosas. Na atual literatura européia, freqüentemente se recorreu ao termo para qualificar o auge dos nacionalismos diferenciais dentro de Estados multiétnicos.

${ }^{5}$ Parto de uma concepção ampliada do político que seja capaz de incluir o que chamamos de religião, ou seja, um sistema normativo que pode reunir o nomos com o cosmos. Assim, os sistemas de peregrinação a santuários panregionais ou os lugares sagrados compartilhados e mesmo o afluxo a mercados regionais podem oferecer dados para a identificação coletiva, embora não respondam a uma lógica política expressa em termos da tradição secular ocidental posterior ao Renascimento.

${ }^{6}$ Já assinalei que este termo é com freqüência utilizado na atualidade para outorgar um maior reconhecimento jurídico ou dignidade cultural aos grupos etnolingüísticos. Mas aqui proponho seu uso em um sentido estrito, em termos de 
uma comunidade de comunicação e de reconhecimento mútuos, que possibilite uma orientação e ação compartilhada em direção ao cumprimento de objetivos públicos. Como comunidades organizadas seriam então Povos, embora não constituídos por Estados, que é a característica distintiva das nações (Bartolomé 2000).

${ }^{7}$ Às vezes não tão "quase", como o demonstra a inexplicável política repressiva do atual Estado chileno (2005), que criminalizou as lutas e as reivindicações do povo mapuche, aplicando a ele a mesma legislação que se utiliza para combater o terrorismo. As populações indígenas - uma das vítimas mais indefesas do terrorismo de Estado gerado pela sangrenta ditadura militar de que padeceu o país inteiro - são agora acusadas de terrorismo.

${ }^{8}$ No surgimento dessa associação, junto com outras organizações camponesas, provavelmente influiu a possibilidade de aceder à posse de terras por meio do programa de reforma agrária desenvolvido na época pelo governo. Entre seus objetivos, encontra-se a luta pela restituição de terras comunais às comunidades indígenas da região do Sonsonate e a freqüente denúncia dos abusos sofridos por indígenas (Chapin 1996:333).

${ }^{9}$ Com relação ao noroeste argentino, Madrazo destacou que o controle regional das grandes propriedades diminuiu a capacidade de ação coletiva do campesinato indígena local, já que a violenta política necessária para a sua instauração os fez não somente perderem a terra, mas também as relações intergrupais e a possibilidade de conceberem objetivos comuns (1994:128). Os prolixos estudos de Lorandi conseguiram identificar que esse campesinato indígena genérico estava integrado por diversos grupos étnicos - os Pulare, os Juríe, os Calchaquíe, os Pacioca, os Tucumano e outros - além de numerosos Mitimae provenientes do Norte. No entanto, os povoados indígenas não perderam seu caráter comunitário nem sua identidade como tal até meados do século XIX, quando o genérico nominativo kolla foi utilizado para designá-los como um conjunto indiferenciado (1992). Morgante (2000) documentou que os kolla da Puna estão agora recorrendo à estruturação de uma complexa mitologia que remete aos Inca, mas da qual não está ausente um catolicismo regional reinterpretado para legitimar sua noção de coletividade étnica.

${ }^{10}$ Depois da Guerra do Pacífico, o norte do Chile foi cenário de um processo de "chilenização" desenvolvido pelo Estado, procurando impor a nova lealdade estatal aos habitantes dos territórios ocupados, fossem eles bolivianos ou peruanos. Os Aymara foram também vítimas dessa compulsão política e ideológica, já que a manutenção de suas tradições culturais nativas era considerada uma evidência de lealdade ao Estado boliviano.

${ }^{11}$ Oliveira Filho (1998) chama de processo de territorialização, o movimento pelo qual as administrações coloniais reestruturaram as sociedades nativas para facilitar seu controle, procurando transformá-las em coletividades organizadas, que formularam uma identificação específica, passaram a ter autoridades unitárias que as representassem e, ao mesmo tempo, modificaram suas relações com o meio ambiente e com sua experiência do sagrado. 
${ }^{12}$ Para esta reflexão sobre a etnogênese, baseio-me em uma proposta anterior a esse respeito e que apresentei recentemente (2004), motivo pelo qual não creio poder acrescentar muito ao que já assinalei naquela oportunidade. Embora eu me referisse a processos que ocorriam em um só país (Argentina), a reflexão parece generalizável a todos os casos que conheço.

${ }^{13}$ Desde meus já distantes tempos de estudante na Argentina, éramos informados de que determinados grupos não existiam, de que estavam muito misturados ou de que a língua se havia perdido. A nós, antropólogos, cabia pesquisar as sociedades "coerentes", dotadas de uma cultura "própria", e não os remanescentes do passado, cujo interesse etnológico seria muito reduzido e sobre os quais só se poderia praticar, eventualmente, algum tipo de "resgate" cultural, salvando do naufrágio dessas culturas algumas tradições para alimentarem nossa vida acadêmica. Pelas observações de alguns colegas brasileiros, aparentemente essa mesma perspectiva determinou a falta de interesse nas populações indígenas do Nordeste, cujo ressurgimento desorienta alguns.

${ }^{14}$ Existe uma vasta literatura etnológica a respeito desse tema, e esse não é um processo exclusivo dos indígenas da América Latina. Muitos indígenas norte-americanos, incluindo seus líderes, desconhecem a língua dos mais velhos. E para lembrar um caso mais dramático, a maior parte dos etarra bascos não fala o euskera, que faz parte da identidade etnonacional pela qual estão dispostos a matar ou a morrer.

${ }^{15}$ Quem contemplar a fotografia da representante dos Tonocoté da Argentina, antes considerados desaparecidos, em um simpósio sobre etnoconhecimentos indígenas realizado em Montreal em junho de 2002, ficará desconcertado diante de sua indumentária obviamente construída com peças de distintas tradições nativas silvícolas e andinas. No entanto, essa aparente "falsificação" não significa, por exemplo, a ausência de membros do chamado Conselho da Nação Tonocoté Llutqui, que agruparia 12 comunidades indígenas, na Jornada Nacional de Rebeldia, ocorrida em 11 de outubro do mesmo ano e da qual participaram ativamente junto com outras combativas organizações políticas.

${ }^{16}$ As visões instrumentalistas de curto alcance também não podem explicar a surpreendente comunicação, ou "conspiração", estabelecida entre comunidades às vezes distanciadas por centenas de quilômetros entre si e que teria produzido a eclosão conjunta da nova afirmação identitária.

${ }^{17}$ Não são raras as propostas discursivas e performativas que líderes e representantes de organizações indígenas costumam desenvolver, perante funcionários e membros de instituições estatais ou grupos de apoio, para enfatizar sua singularidade em termos que julgam mais compreensíveis a seus interlocutores - ou seja, valem-se de emblemas materiais ou retóricos que, supõem, serão capazes de surtir o efeito desejado; na maioria dos casos, não se trata de um ato de falsificação, mas de uma tentativa de comunicação, na qual se recorre a signos considerados apropriados para o tipo de interação. Assim, por exemplo, uma jovem mapuche presente a um congresso antropológico, vestida com roupas juvenis, se enfeitará com suas vestimentas e 
AS ETNOGÊNESES: VELHOS ATORES E NOVOS PAPÉIS NO CENÁRIO CULTURAL E POLÍTICO

jóias tradicionais quando lhe parecer pertinente expor esses elementos. O risco é ver mera teatralidade em contextos nos quais se está tentando um diálogo que sublinhe a diferença entre os participantes, sem negar a comunicação possível.

\section{Referências bibliográficas}

AGIER, Michel. 2001. "Distúrbios identitários em tempos de globalização". Mana. Estudos de Antropologia Social, 7(2):7-33.

ANDERSON, Benedict. 1993. Comunidades imaginadas: reflexiones sobre el origen y la difusión del nacionalismo ( $2^{\mathrm{a}}$ edição). México, DF: Fondo de Cultura Económica.

ARRUTI, José M. Andion. 1997. "A emergência dos 'remanescentes': notas para o diálogo entre indígenas e quilombolas". Mana. Estudos de Antropologia Social, 3(2):7-38.

ARVELO-JIMENEZ, Nelly. 2001. "Movimientos etnopolíticos contemporáneos y sus raíces organizacionales en el sistema de interdependencia regional del Orinoco". Série Antropologia, 309.

BARABAS, Alicia. 1989. Utopias indias: movimientos socioreligiosos en México. Colección Enlace. México, DF: Editorial Grijalbo.

2000. "La construcción del indio como bárbaro: de la etnografía al indigenismo". Alteridades, 19:9-20.

BARABAS, Alicia e BARTOLOMÉ, Miguel. 1999. Configuraciones étnicas en Oaxaca: perspectivas etnográficas para las autonomías, III Tomos. México, DF: INAH-INI.

2003. Historias y palabras de los antepasados: investigación y devolución social de la información antropológica. Oaxaca, México: Ed. Gobierno del Estado.

BARTOLOMÉ, Miguel Alberto. 1969. "Los guaná y sus jefes". Suplemento Antropológico, 4(1):135-148.

1977. Chamanismo y religión entre los Avá-Katú-Eté del Paraguay. Serie de Antropología Social n 17. México, DF: Instituto Indigenista Interamericano ( $2^{\mathrm{a}}$ ed. 1991. Asunção: Biblioteca Paraguaya de Antropología, $\mathrm{n}^{\circ}$ 11). 1985. "La desindianización de la Argentina". Boletín de Antropología Americana, 11:39-50.

1988. La dinamica social de los Mayas de Yucatán: pasado y presente de la situación colonial. Serie de Antropología Social, no 80. México, DF: Instituto Nacional Indigenista.

. 1996. "La extinción del ixcateco: la identidad étnica ante la pérdida lingüística". In: M. Bartolomé y A. Barabas, La pluralidad en peligro. México, DF: INAH. pp. 101-128. 1997. Gente de costumbre y gente de razón: las identidades étnicas en México. México, DF: Siglo XXI-INI Editores. 2a ed.: 2004. 2000. "Etnias y naciones: la construcción civilizatoria en América Latina". In: L. Reina (org.), Los retos de la etnicidad en los estados-nación del siglo XXI. México, DF: CIESASINI-PORRUA. pp. 153-170. 
2000a. El encuentro de la gente y los insensatos: la sedentarizacion de los cazadores ayoreo en el Paraguay. México, DF: Instituto Indigenista Interamericano-Centro de Estudios Antropológicos del Paraguay.

. 2001. "Las palabras de los otros: la antropología escrita por indígenas en Oaxaca". Anuario Antropológico, 7:43-87.

. 2004. "Los pobladores del desierto: genocidio, etnocidio y etnogénesis en Argentina". In: P. Petrich (org.), Positionnements identitaries des groupes indiens d'Amerique latine. Paris: ALHIM/ Université Paris 8. pp. 45-72.

BARTOLOMÉ, Miguel y BARABAS, Alicia. 1977. La resistencia maya: relaciones interétnicas en el oriente de la península de Yucatán. México, DF: INAH. Serie Científica, $n^{\circ}$ 53. $2^{\mathrm{a}}$ ed: 1982 1996. La pluralidad en peligro: procesos de extinción y transfiguración étnica en Oaxaca. México, DF: INAH-INI. Col.Regiones.

BOCCARA, Guillaume. 2000. "Antropología diacrónica: dinámicas culturales, procesos históricos y poder político". In: G. Boccara e S. Galindo (orgs.), Lógica mestiza en América. Temuco, Chile: Universidad de la Frontera, Instituto de Estudios Indígenas. pp. 11-59.

CARVALHO, María do Rosário. 1984. "A identidade dos povos do Nordeste". Anuário Antropológico, 82:169-188.

CHAPIN, Mac. 1996. "La población indígena del Salvador". In: A. Medina (org.), La etnografía de Mesoamerica Meridional y el Área Circuncaribe. México, DF: IIA-UNAM. pp. 299-339.

ERIKSEN, Thomas Hylland. 1993. Ethnicity \& nationalism: anthropological perspectives. London: Pluto Press.

FRIDMANN, Nina e AROCHA, Jaime. 1986. De sol a sol. Génesis, transformación y presencia de los negros en
Colombia. Bogotá: Planeta Editorial. GARCIA, Alejandro. 2002. "Una mirada a los reclamos modernos de identidad huarpe". Scripta Nova. Revista Electrónica de Geografía y Ciencias Sociales, VI(109).

GARCIA LINERA, Alvaro. 2005. "Autonomías indígenas". In: F. Escárcega y R. Gutierrez (orgs.), Movimiento indígena en América Latina. Resistencia y proyecto alternativo. México, DF: Juan Pablos Ed. pp. 273-292.

GHIDINELLI, Azzo. 1983. "Los grupos humanos que se originaron después de la conquista en la costa atlántica de Guatemala y Honduras". In: Memorias del seminario de la costa atlántica de Centroamérica. San José, Costa Rica: CSUCA.

GONZALEZ CORTEZ, Héctor. 1997. "Apuntes sobre el tema de la identidad en la región de Tarapacá". Estudios Atacameños, 13:27-46.

GOULD, Jeffrey. 1998. To die in this way: Nicaraguan indians and the myth of mestizaje, 1880-1965. Durham and London: Duke University Press.

GOW, Peter. 2003. “Ex-cocama: identidades em transformação na Amazônia peruana". Mana. Estudos de Antropología Social, 9(1):57-79.

GROS, Christian. 2000. Políticas de la etnicidad: identidad, estado y modernidad. Bogotá, Colombia: Instituto Colombiano de Antropología e Historia.

GUNDERMANN KRÖLL, Hans. 1997. "Etnicidad, identidad étnica y ciudadanía en los países andinos y el norte de Chile". Estudios Atacameños, 13:9-26.

GUSS, David. 1996. "Cimarrones, theater and the state". In: J. Hill (org.), History, power and identity. Iowa, USA: University of Iowa Press. pp. 180-192.

HILL, Jonathan (org). 1996. History, power and identity. Iowa, USA: University of Iowa Press. 
1996a. "Ethnogénesis in the

Norhwest Amazon: an emerging regional picture". In: History, power and identity. Iowa, USA: University of Iowa Press. pp. 142-160.

HOBSBAWM, Eric e RANGER, Terence (orgs.). 1983. The invention of tradition. Cambridge, UK: Cambridge University Press.

HRYB, Olexander. 2000. "Soviet ethnography heritage and the revival of ethnogeopolitics in Russia and Ukraine". Ponencia presentada al REECAS-NW Conference. USA: Tacoma.

LÓPEZ AUSTIN, Alfredo e LÓPEZ LUJAN, Leonardo. 1996. Mito y realidad de zuyua. México, DF: FCE-CM.

LORANDI, Ana María e DEL RIO, Mercedes. 1992. Etnohistoria: etnogénesis y transformaciones sociales andinas. Buenos Aires: Centro Editor de América Latina.

MADRAZO, Guillermo. 1994. "Historia de un despojo: el indigenado del noroeste argentino y su transformación campesina". Andes: Antropología e Historia, 6:127-156.

MANTOANELLI, Luz Edward. 2004. “Da sublimação voluntária à reconstrução da identidade kokama no Brasil". Trabalho apresentado no V Congreso de la Asociación de Antropología Chilena, San Felipe, Chile.

MORGANTE, Maria Gabriela. 2000 "Entre el pasado y el presente: el relato mítico y el tema de la identidad en la Puna argentina". Trabalho apresentado no VI Congreso Argentino de A. Social, Argentina, Mar del Plata.

NÁSSER, Nássaro e CABRAL NÁSSER, Elizabeth. 1988. "Os Tuxá - incorporação à história". In: Pedro Agostinho (org.), O índio na Bahia. Salvador: Fundação Cultural do Estado da Bahia.

OCHOA ARIAS, Ana Manuela. 2005. "Tejiendo la historia. Notas sobre el proceso de reconstrucción del pueblo kankuano". In: Página web CLAJADEP, Ciberespacio.

O'DWYER, Eliane Cantarino. 2002. Quilombos: identidade étnica e territorialidade. Rio de Janeiro: FGV / ABA.

OLIVEIRA FILHO, João Pacheco de. 1998. "Uma etnologia dos 'índios misturados'? Situação colonial, territorialização e fluxos culturais". Mana. Estudos de Antropología Social, 4(1):47-77.

PEREZ, Antonio. 2001. "De la etnoescatología a la etnogénesis: notas sobre las nuevas identidades étnicas". Revista de Antropología Experimental, 1.

PETESCH, Natalie. 2003. "Los cocama nacen en el Perú: migración y problemas de identidad entre los cocama del río Amazonas". Antropológica, 21.

PORTO ALEGRE, Maria Sylvia. 1998. "Rompendo o silêncio: por uma revisão do "desaparecimento" dos povos indígenas". Ethnos: Revista Brasileira de Etnohistoria, 2(2).

REDFIELD, Robert; LINTON, Ralph e HERSKOVITS, Melville. 1936. "Memorandum of the study of acculturation". American Anthropologist, XXXVIII:149-152.

RIVERA FLORES, Francisco. 1997. "Procesos de articulaciones socioidentitarias y reformulaciones étnicas en Atacama". Estudios Atacameños, 13:61-74.

2004. "Anti-flexibilización con identidad/alteridad: la cuestión étnica atacameña y su contexto neoliberal-flexible. Revista de Antropología Experimental, 4.

ROOSENS, Eugeen. 1989. Creating ethnicity. The process of ethnogenesis. San Francisco, USA: Ed. Sage.

SIDER, Gerald M. 1976. "Lumbee indian cultural nationalism and ethnogenesis". Dialectical Anthropology, 1(2):161-172.

UNRUTH, Ernesto e KALISCH, Hannes. 1999. Vana peema: guía del maestro 
Maskoy para el aprendizaje del idioma guaná. Chaco, Paraguay: Equipo Materiales Enlhet. Folheto publicado em Ya'alve-Saanga.

WHITEHEAD, Neil Lancelot. 1996. "Ethnogénesis and ethnocide in the european occupation of native Surinam, 1499-1681". In: J. Hill (org.). History, power and identity. Iowa, USA: University of Iowa Press. pp. 20-35.

ZAMBRANO, Carlos Vladimir. 2000. "Mito y etnicidad entre los Yanaconas del macizo colombiano". Mitológicas, $\mathrm{XV}: 19-36$ 


\section{Resumo}

Os distintos usos do conceito de etnogêneses remetem a um mesmo tipo de dinâmica social, cuja base se encontra na historicidade de estruturas e formas culturais que tendiam a se conceberem como relativamente estáticas. A etnogênese, ou melhor, as etnogêneses referem-se ao dinamismo inerente aos agrupamentos étnicos, cujas lógicas sociais revelam uma plasticidade e uma capacidade adaptativa que nem sempre foram reconhecidas pela análise antropológica. Na verdade, a etnogênese foi e é um processo histórico constante que reflete a dinâmica cultural e política das sociedades anteriores ou exteriores ao desenvolvimento dos Estados nacionais da atualidade. A etnogênese é parte constitutiva do próprio processo histórico da humanidade e não só um dado do presente, como parecia depreenderse das reações de surpresa de alguns pesquisadores sociais em face de sua evidência contemporânea.

Palavras-chave: Etnogêneses, Etnicidade, Indígenas, América Latina

\section{Abstract}

The different uses of the concept of ethnogenesis refer to the same type of social dynamic, based on the historicity of cultural structures and forms that are more usually taken to be relatively static. The idea of ethnogenesis - or better, ethnogeneses - refers to the dynamism inherent to ethnic groups, whose social logics reveal a plasticity and adaptive capacity not always recognized by anthropological analysis. In fact, ethnogenesis was and is a continual historical process that reflects the cultural and political dynamic of societies anterior or exterior to the development of today's national States. Ethnogenesis is a constitutive part of the historical process of humanity itself and not just a fact of the present, as can be deduced, perhaps, from the surprise shown by some social researchers when faced with its contemporary effervescence.

Key words: Ethnogenesis, Ethnicity, Indigenous Peoples, Latin America 